\section{Quality Changes During Storage and Ripening of 'Tommy Atkins' Mangos Treated with Heated Forced Air}

\author{
W.R. Miller and R.E. McDonald \\ U.S. Department of Agriculture, Agricultural Research Service, U.S. \\ Horticultural Research Laboratory, 2120 Camden Road, Orlando, \\ FL 32803
}

\section{J.L. Sharp \\ U.S. Department of Agriculture, Agricultural Research Service, Subtropical Horticultural Research Laboratory, 13601 Old Cutler Road, Miami, FL 32158}

Additional index words. Mangifera indica, Caribbean fruit fly, Anastrepha suspensa, quarantine procedures, condition, postharvest

\begin{abstract}
Freshly harvested mangos (Mangifera indica L.) treated with forced air at 51.5C for 125 minutes then stored for 1,2 , or 3 weeks at 12C, followed by $21 \mathrm{C}$ until soft-ripe, were compared with nontreated fruit for quality changes. Treated fruit lost 1.0\% more fresh weight than nontreated fruit and deveoped trace amounts of peel pitting. Total soluble solids concentrations for treated and nontreated fruit were similar $(\approx 13 \%)$, as was peel color at the soft-ripe stage. Treated fruit generally reached the soft-ripe stage $\approx 1$ day earlier than nontreated fruit regardless of storage duration and had a lower incidence and severity of stem-end rot and anthracnose. The trace of pitting on treated fruit likely will not influence consumer acceptance.
\end{abstract}

Florida-grown mangos must be subjected to a quarantine treatment for Caribbean fruit fly (CFF) larvae [Anastrepha suspensa (Loew)] before shipment to certain domestic or export markets [Animal and Plant Health Inspection Serv. (APHIS), 1986]. Following the ban of ethylene dibromide as a postharvest fumigant by the U.S. Environmental Protection Agency in 1984 (Federal Register, 1984), a hot-water immersion quarantine treatment for interstate trade of Florida-grown mangos (Sharp and Spalding, 1984) and importation of Haitian-grown 'Francis' (Sharp et al., 1988) and Mexican-grown mangos (Sharp et al., 1989a, 1989b) was approved (APHIS, 1986).

Alternative quarantine treatments using low temperature, irradiation, vapor heat, or hightemperature air are accepted quarantine methods for other fresh fruits (APHIS, 1986). However, low temperatures cannot be used for mangos because they develop chilling injury. Vapor heat (treatment with condensation on fruit) effectively disinfested the mangos of the melon fly (Dacus cucurbitae Coquillett) without injuring the fruit (Sunagawa et al., 1987). Vapor-heat treatments of

Received for publication 31 July 1990. Mention of a trademark, warranty, proprietary product, or vendor does not constitute a guarantee by the U.S. Dept. of Agriculture and does not imply its approval to the exclusion of other products or vendors that may also be suitable. We acknowledge the technical assistance of C. Carroll, R. Duncan, and W. Reeder during the course of this study. The cost of publishing this paper was defrayed in part by the payment of page charges. Under postal regulations, this paper therefore must be hereby marked advertisement solely to indicate this fact. tain the desired treatment environment (temperature/relative humidity/air velocity) and to prevent the accumulation of free water on the fruit surface during treatment (Gaffney and Armstrong, 1990). The treatment consisted of exposing mangos to air at a maximum of $51.5 \mathrm{C}( \pm 0.2 \mathrm{C})$ for $125 \mathrm{~min}$ at an airflow of $\approx 0.4 \mathrm{~m}^{3} \cdot \mathrm{s}^{-1}$. During treatment, incoming air temperature was increased to maintain a 2-degree differential between the incoming air and the fruit surface to prevent condensation. Treatment time continued until the fruit core temperature had reached and maintained $43.5 \mathrm{C}$ for $20 \mathrm{~min}$. Total treatment time was $125 \mathrm{~min}$ for each of the three tests. Copper/constantan thermocouples (36 gauge; $0.127 \mathrm{~mm}$ in diameter) were inserted $1 \mathrm{~mm}$ below the peel surface of six fruit and adjacent to the seed in six fruit to monitor fruit surface and near-core temperatures, respectively. Temperatures were recorded by computer and used to control air temperatures entering the test chamber. Mangos used for monitoring pulp temperatures were placed among fruit located at the end opposite from incoming heated air to ensure that all fruit reached the target temperature. After treatment, fruit were placed at ambient room temperature $(\approx 25 \mathrm{C})$ and, when at equilibrium, were washed with tap water on a roller brush bed and dried with warm air. Mangos were placed into full-telescoping, fiberboard boxes, eight fruit per box, in a single layer. Packaged mangos were taken to the U.S. Horticultural Research Laboratory, Orlando, Fla., within $5 \mathrm{~h}$ after treatment, initially inspected, and stored at $12 \mathrm{C}$ and $90 \% \pm 5 \%$ relative humidity $(\mathrm{RH})$. Twenty-four treated and 24 nontreated mangos were removed, inspected, and evaluated after 1, 2, or 3 weeks of $12 \mathrm{C}$ storage. After inspection, the fruit were ripened at $21 \mathrm{C}$. Fruit were observed daily during ripening, and those mangos that had reached the soft-ripe stage were given a final evaluation.

Mangos were weighed during each inspection and subjectively evaluated for peel color, peel discoloration, surface pitting, firmness, decay, and freshness of appearance.

Peel color was subjectively scored on a scale of 1 to 5 , where $1=100 \%$ green (no ground color, i.e., yellow or red), $2=1 \%$ to $25 \%, 3=26 \%$ to $50 \%, 4=51 \%$ to $75 \%$, and $5=76 \%$ to $100 \%$ ground color. Peel discoloration (scald) and pitting were scored on a scale of 1 to 5 , where $1=$ none, $2=$ less than $2 \%, 3=3 \%$ to $10 \%, 4=$ $11 \%$ to $25 \%$, and $5=$ greater than $25 \%$ of surface area. Firmness was subjectively rated on a scale of 1 to 5 , where $1=$ overripe [very soft, very slight resistance to moderately applied finger pressure (MAFP)], 2 = soft-ripe (eating stage, slight resistance to MAFP), 3 = fairly soft (moderate yield to MAFP), 4 = fairly hard (slight yield to MAFP), and 5 = hard (no yield to MAFP). External appearance (freshness) of fruit was rated on a scale of 1 to 3 , where $1=$ fresh (smooth surface, good color with gloss), 2 $=$ fairly fresh (smooth surface, slightly dull color and moderate gloss), and $3=$ old (rough 
Table 1. Fruit quality characteristics of 'Tommy Atkins' mangos after treatment with $51.5 \mathrm{C}$ air for $125 \mathrm{~min}$ and stored for 1,2 , or 3 weeks at $12 \mathrm{C}$, then held at $21 \mathrm{C}$ until soft-ripe.

\begin{tabular}{|c|c|c|c|c|c|c|c|}
\hline \multirow{2}{*}{$\begin{array}{l}\text { Storage duration/ } \\
\text { trcatment }\end{array}$} & \multirow{2}{*}{$\begin{array}{c}\text { Wt loss } \\
(\%)\end{array}$} & \multirow{2}{*}{$\begin{array}{l}\mathrm{Pit}^{\mathrm{z}} \\
\text { rating }\end{array}$} & \multirow{2}{*}{$\begin{array}{c}\text { SER } \\
\text { rating }\end{array}$} & \multirow{2}{*}{$\begin{array}{c}\text { ANTH } \\
\text { rating }\end{array}$} & \multicolumn{3}{|c|}{ Fruit eliminated $(\%)$ due to } \\
\hline & & & & & SER & ANTH & Decay \\
\hline \multicolumn{8}{|l|}{ Initial } \\
\hline Control & 0.0 & $1.0 \mathrm{a}^{\mathrm{x}}$ & $1.0 \mathrm{a}$ & $1.0 \mathrm{a}$ & 0.0 & $0.5 \mathrm{a}$ & 0.0 \\
\hline Heated & 0.0 & $1.1 \mathrm{~b}$ & $1.0 \mathrm{a}$ & $1.1 \mathrm{~b}$ & 0.0 & $0.0 \mathrm{a}$ & 0.0 \\
\hline \multicolumn{8}{|l|}{1 Week } \\
\hline Control & $2.1 \mathrm{a}$ & $1.0 \mathrm{a}$ & $1.0 \mathrm{a}$ & $1.3 \mathrm{a}$ & 0.0 & $0.6 \mathrm{a}$ & 0.0 \\
\hline Heated & $3.1 \mathrm{a}$ & $1.6 \mathrm{~b}$ & $1.0 \mathrm{a}$ & $1.2 \mathrm{~b}$ & 0.0 & $0.0 \mathrm{a}$ & 0.0 \\
\hline \multicolumn{8}{|c|}{1 Week then soft-ripe } \\
\hline Control & $5.6 \mathrm{a}$ & $1.0 \mathrm{a}$ & $4.0 \mathrm{a}$ & $3.7 \mathrm{a}$ & $69.4 \mathrm{a}$ & $34.7 \mathrm{a}$ & 72.2 \\
\hline Heated & $5.3 \mathrm{a}$ & $1.6 \mathrm{~b}$ & $2.1 \mathrm{~b}$ & $2.1 \mathrm{~b}$ & $25.0 \mathrm{~b}$ & $0.0 \mathrm{~b}$ & 25.0 \\
\hline 2 Weeks & & & & & & & \\
\hline Control & $3.3 \mathrm{a}$ & $1.0 \mathrm{a}$ & $1.2 \mathrm{a}$ & $2.5 \mathrm{a}$ & $4.9 \mathrm{a}$ & $5.6 \mathrm{a}$ & 8.3 \\
\hline Heated & $4.3 \mathrm{~b}$ & $1.8 \mathrm{~b}$ & $1.2 \mathrm{a}$ & $1.8 \mathrm{~b}$ & $4.2 \mathrm{a}$ & $0.7 \mathrm{~b}$ & 4.2 \\
\hline \multicolumn{8}{|c|}{2 Wecks then soft-ripe } \\
\hline Control & $5.2 \mathrm{a}$ & $1.0 \mathrm{a}$ & $4.3 \mathrm{a}$ & $4.2 \mathrm{a}$ & $76.4 \mathrm{a}$ & $50.0 \mathrm{a}$ & $79.2 \mathrm{a}$ \\
\hline \multirow{2}{*}{\multicolumn{8}{|c|}{3 Wceks }} \\
\hline & & & & & & & \\
\hline Control & $4.3 \mathrm{a}$ & $1.0 \mathrm{a}$ & $2.7 \mathrm{a}$ & $3.8 \mathrm{a}$ & $36.1 \mathrm{a}$ & $30.6 \mathrm{a}$ & $45.8 \mathrm{a}$ \\
\hline Heated & $5.3 \mathrm{~b}$ & $1.9 \mathrm{~b}$ & $2.2 \mathrm{~b}$ & $2.8 \mathrm{~b}$ & $30.6 \mathrm{a}$ & $12.5 \mathrm{~b}$ & $30.6 \mathrm{~b}$ \\
\hline \multicolumn{8}{|c|}{3 Weeks then soft-ripe } \\
\hline Control & $5.2 \mathrm{a}$ & $1.0 \mathrm{a}$ & $4.6 \mathrm{a}$ & $4.4 \mathrm{a}$ & 84.7 a & $61.1 \mathrm{a}$ & $88.9 \mathrm{a}$ \\
\hline Heated & $5.9 \mathrm{~b}$ & $1.7 \mathrm{~b}$ & $3.3 \mathrm{~b}$ & $3.0 \mathrm{~b}$ & $50.0 \mathrm{~b}$ & $11.1 \mathrm{~b}$ & 52.8 \\
\hline
\end{tabular}

${ }^{\mathrm{z}} \mathrm{Pit}=$ pitting, SER $=$ stem-end rot, and ANTH $=$ anthracnose ratings: where $1=$ none, $2=$ trace, $3=$ slight, $4=$ moderate, and $5=$ severe.

${ }^{\gamma}$ Percentage decay may not equal sum of SER and ANTH because some fruit were eliminated with both severe SER and ANTH.

${ }^{\mathrm{x}}$ Mean separation within column groups (treated or nontreated by storage or ripening time) by $\mathrm{F}$ test, $P<0.05$.

Table 2. Fruit characteristics and days to soft-ripe stage for 'Tommy Atkins' mangos after treatment with $51.5 \mathrm{C}$ air for $125 \mathrm{~min}$ and then stored for 1,2 , or 3 weeks at $12 \mathrm{C}$ followed by holding at $21 \mathrm{C}$ until soft-ripe. ${ }^{\mathrm{z}}$

\begin{tabular}{|c|c|c|c|c|c|c|c|c|}
\hline \multirow{2}{*}{$\begin{array}{l}\text { Storage/ } \\
\text { treatment }\end{array}$} & \multirow{2}{*}{$\begin{array}{c}\text { Firmness } \\
(\mathrm{N})\end{array}$} & \multirow{2}{*}{$\begin{array}{c}\text { Freshness } \\
\text { ratingy }\end{array}$} & \multirow{2}{*}{$\begin{array}{c}\text { Peel color } \\
\text { rating }^{\mathbf{x}}\end{array}$} & \multicolumn{3}{|c|}{ Pulp color ${ }^{w}$} & \multirow{2}{*}{$\begin{array}{l}\text { TSS } \\
(\%)\end{array}$} & \multirow{2}{*}{$\begin{array}{r}\text { Days to } \\
\text { soft-ripe }\end{array}$} \\
\hline & & & & 'L' & ' $\mathrm{a}$ ' & 'b' & & \\
\hline \multicolumn{9}{|c|}{1 Week then soft-ripe } \\
\hline Control & $0.5 \mathrm{a}$ & $2.2 \mathrm{a}$ & $5.0 \mathrm{a}$ & $64.9 \mathrm{a}$ & $8.3 \mathrm{a}$ & $61.1 \mathrm{a}$ & $12.7 \mathrm{a}$ & $9.6 \mathrm{a}$ \\
\hline $\begin{array}{l}\text { Heated } \\
2 \text { Weeks }\end{array}$ & $0.8 \mathrm{~b}$ & $1.6 \mathrm{a}$ & $4.8 \mathrm{~b}$ & $67.0 \mathrm{~b}$ & $5.7 \mathrm{~b}$ & $49.4 \mathrm{a}$ & $13.2 \mathrm{a}$ & $7.0 \mathrm{a}$ \\
\hline \multicolumn{9}{|c|}{2 Weeks then } \\
\hline Hcated & 0 & 1.7 & $=1$ & $8.1 \mathrm{~b}$ & $5.4 \mathrm{~b}$ & $40.6 \mathrm{~b}$ & $13.3 \mathrm{~b}$ & 5.2 \\
\hline \multicolumn{9}{|c|}{3 Weeks then soft-ripe } \\
\hline Control & $0.5 \mathrm{a}$ & $2.6 \mathrm{a}$ & $5.0 \mathrm{a}$ & $66.0 \mathrm{a}$ & $5.7 \mathrm{a}$ & $60.2 \mathrm{a}$ & $13.2 \mathrm{a}$ & $3.1 \mathrm{a}$ \\
\hline Heated & $0.7 \mathrm{~b}$ & $2.1 \mathrm{~b}$ & $5.0 \mathrm{a}$ & $68.0 \mathrm{~b}$ & $4.5 \mathrm{~b}$ & $61.0 \mathrm{a}$ & $13.0 \mathrm{a}$ & $2.4 \mathrm{~b}$ \\
\hline
\end{tabular}

${ }^{\mathrm{z}}$ Mean separation within column groups (treated or nontreated by storage time) by $\mathrm{F}$ test, $P \leq 0.05$.

${ }^{\mathrm{r}} 1$ = Fresh, 2 = fairly fresh, and $3=$ not fresh.

${ }^{x} 1=$ green, $2=$ less than $25 \%$ yellow $/$ red, $3=26 \%$ to $50 \%, 4=51 \%$ to $75 \%$, and $5=$ greater than $75 \%$ yellow/red peel area.

whunter color values.

Days for fruit to reach the soft-ripe stage after being placed at $21 \mathrm{C}$.

surface, dull color without gloss).

The severity of rot for each fruit was scored on a scale of 1 to 5 based on the area of the fruit affected (Miller et al., 1986). Each fruit was scored for both anthracnose (ANTH) (Colletotrichum gloeosporioides Penz) or stem-end rot (SER) (Diplodia natalensis P. Evans). Any fruit with a decay severity of 5 was eliminated from the test.

The number of days each fruit remained at $21 \mathrm{C}$ until reaching soft-ripe was recorded, and the pulp firmness and color were determined objectively. Soft-ripe mangos were assayed for total soluble solids concentration (TSS) (refractometer) and pulp color (Minolta Calorimeter, Model CR 200, Osaka, Japan). After removal of a thin section of peel with a scalpel, pulp firmness was determined with an Instron Food Texture System (Model
1132; Instron Corp., Canton, Mass.) calibrated to apply a $10-\mathrm{kg}$ force at $50-\mathrm{mm} \cdot \mathrm{min}^{-1}$ travel speed and set to penetrate the pulp 10 $\mathrm{mm}$ with a 9.5-mm-diameter cylinder. Each fruit was then cut through parallel to each side of the characteristically flat seed, and three color measurements were made on the flat pulp surface of each half. Additional subjective observations were made for visible discoloration of pulp tissue, especially areas containing vascular bundles. Pulp was then diced and a 100-g sample was squeezed by mechanical press to obtain juice for measuring TSS by refractometer. Pulp not destroyed was evaluated for flavor by an informal taste panel of seven individuals and scored as either 1 (acceptable) or 2 (not acceptable).

The means for all characteristics from three tests (replications) were subjected to analysis of variance (SAS, 1982) procedures.

Treated fruit had lost significantly $(P<$ 0.05 ) more weight than nontreated fruit after 2 weeks and this difference was maintained until the fruit became soft-ripe (Table 1). Treated fruit developed only a trace of pitting and that within 1 week after treatment. Peel pitting was manifested as small, irregularly shaped, slightly sunken, and shriveled areas. Pitting usually appeared on fruit epidermis at areas previously bruised or abraded during harvesting and handling operations. No pitting was observed on nontreated fruit. Peel discoloration, such as scald, was not observed on any treated or nontreated fruit.

SER increased with storage time and was more prevalent in nontreated than in treated fruit at the soft-ripe stage, regardless of storage duration at $12 \mathrm{C}$. ANTH also increased with storage time, and the decay severity was significantly $(P<0.05)$ greater in nontreated than in treated fruit. At the soft-ripe stage, nontreated fruit had significantly $(P<0.05)$ more SER $(1.6$-fold $)$ than the treated fruit. Decay $($ score $=5)$ eliminated $49 \%$ of treated or nontreated mangos after 1 week of storage and $\approx 71 \%$ after 3 weeks in all tests.

Treated mangos tended to reach the softripe stage earlier and they were slightly firmer than nontreated fruit (Table 2). Treated fruit were fresher in appearance than nontreated fruit after storage and ripening. Peel color was similar for treated and nontreated mangos on reaching the soft-ripe stage, regardless of storage duration. The pulp of treated fruit had consistently higher ' $L$ ' values (lighter in color) and lower ' $a$ ' values (more green, less red) than nontreated fruit. There was no significant $(P<0.05)$ difference in ' $\mathrm{b}$ ' values among treatments, except after 2 weeks. Average TSS values for soft-ripe fruit for all storage durations were $12.8 \%$ and $13.2 \%$ for nontreated and treated mangos, respectively. Treated fruit generally had higher TSS than nontreated mangos, but this difference was significant $(P<0.05)$ only for mangos ripened after 2 weeks of storage. Although treated mangos consistently were soft-ripe $\approx 1$ day earlier than nontreated fruit, the objective firmness and pulp color values indicated that these fruit were less ripe. Perhaps the treatment caused the outer pulp to soften earlier than in nontreated fruit.

Mean flavor scores ranged from 1.1 to 1.4 on reaching soft-ripe after storage of 1,2 , or 3 weeks at $12 \mathrm{C}$. There were no detectable differences between treated or nontreated fruit. Taste deteriorated slightly but not significantly as storage duration increased.

Treatment of 'Tommy Atkins' mangos at $51.5 \mathrm{C}$ air for $125 \mathrm{~min}$ followed by storage and ripening conditions did not adversely affect fruit quality. Although the high-temperature, forced-air treatment caused slight pitting $(<2 \%)$, this condition should not affect fruit marketability. Pitting usually appeared at sites of abrasions caused by rough handling before treatment. The treatment did not lead to 
an objectionable fruit flavor. A secondary benefit of this heat treatment was a reduction in the development of SER and ANTH rot. Our data differ from those of Spalding et al. (1988) in that they reported that a 46C or 49C water-immersion treatment reduced SER but not ANTH rot, whereas our data indicated a reduction in both types of decay. Additional testing of mangos should be conducted to determine the effects of seasonal and cultivar differences in response to hightemperature, forced-air treatments.

\section{Literature Cited}

Animal and Plant Health Inspection Service. 1986. Plant protection and quarantine treatment manual, M319.56-2-A. Section VI-T102.

Federal Register. 1984. Ethylene dibromide: Amendment of notice to cancel registration of pesticide products containing ethylene dibromide. Federal Register 49:14182-14185. U.S. Government Printing Office, Washington, D.C.

Armstrong, J.W., J.D. Hanson, B.K.S. Hu, and S.A. Brown. 1989. High-temperature, forcedair quarantine treatment for papayas infested with Tephritid fruit flies (Diptera: Tephritidae). J. Econ. Entomol. 82:1667-1674.

Gaffney, J.J. and J.W. Armstrong. 1990. Hightemperature forced-air research facility for heating fruits for insect quarantine treatments. J. Econ. Entomol. 83:1959-1964.

Miller, W.R., D.H. Spalding, and P.W. Hale. 1986. Film wrapping mangos at advancing stages of postharvest ripening. Trop. Sci. 26:9-17.

SAS Institute. 1982. SAS user's guide: Statistics. SAS Institute, Cary, N.C.

Sharp, J.L. 1989. Preliminary investigation using hot air 10 disinfest grapefruit of Caribbean fruit fly immatures. Proc. Fla. State Hort. Soc. 102:157-159.

Sharp, J.L., M.T. Ouye, S.J. Ingle, and W.G. Hart. 1989a. Hot-water quarantine treatment for mangos from Mexico infested with Mexican fruit fly and West Indian fruit fly (Diptera: Tephritidae). J. Econ. Entomol. 82:1657-1662.

Sharp, J.L., M.T. Ouye, S.J. Ingle, W.G. Hart, W.R. Enkerlin, H.H. Celedonio, J.A. Toledo, L. Stevens, E. Quintero, J.F. Reyes, and A. Schwarz. 1989b. Hot-water quarantine treatment for mangos from the state of Chiapas, Mexico, infested with Mediterranean fruit fly and Anastrepha serpentina (Wiedemann) (Diptera:Tephritidae). J. Econ. Entomol. 82:16631666.

Sharp, J.L., M.T. Ouye, R. Thalman, W. Hart, S. Ingle, and V. Chew. 1988. Submersion of 'Francis' mango in hot water as a quarantine treatment for the West Indian fruit fly and the Caribbean fruit fly (Diptera: Tephritidae). J. Econ. Entomol. 81:1432-1436.

Sharp, J.L. and D.H. Spalding. 1984. Hot water as a quarantine treatment for Florida mangos infested with Caribbean fruit fly. Proc. Fla. State Hort. Soc. 97;355-357.

Spalding, D.H., J.R. King, and J.L. Sharp. 1988. Quality and decay of mangos treated with hot water for quarantine control of fruit fly. Trop. Sci. 28:95-101.

Sunagawa, K., K. Kume, and R. Iwaizumi. 1987. The effectiveness of vapor heat treatment against the melon fly, Dacus cucurbitae Coquillett, in mango and fruit tolerance to the treatment. Res. Bul. Plant Protection Japan 23:13-20. 